\title{
DESCRIPTION OF A NEW WOLF SPIDER IN THE GENUS PIRATA (ARANEAE: LYCOSIDAE)*
}

\author{
By C. D. Dondale and J. H. Redner \\ Biosystematics Research Institute, Agriculture Canada, \\ Ottawa, Ontario K1A 0C6
}

\section{INTRODUCTION}

The genus Pirata Sundevall consists of rather small, active wolf spiders that frequent the vegetation of bogs, swamps, margins of ponds and streams, and, more rarely, salt marshes. In a recent revision, Wallace and Exline (1978) divided the North American species of Pirata into groups based on genitalia, body size, leg setation, and color pattern on the carapace. Their insularis group contained two species, namely, $P$. insularis Emerton, which ranges from the western part of the Northwest Territories to New Brunswick and southward to Arizona and Florida, and P. cantralli Wallace and Exline, which was known only from Michigan and Ontario. Subsequent collections of cantralli indicate that it ranges as widely in Canada as insularis, though southward only to Michigan.

Wallace and Exline (1978) noted the presence of a prominent, basally-directed tooth on the median apophysis of the male palpus of both $P$. insularis and $P$. cantralli. This tooth is absent in representatives of other North American groups of Pirata, but is present in males of certain Palaearctic species of the genus such as $P$. piccolo Dahl (Holm, 1947, Fig. 9; Fuhn and Niculescu-Burlacu, 1971, Fig. 103c), P. japonicus Tanaka (Tanaka, 1974, Fig. 14), P. procurvus (Bösenberg and Strand) (Tanaka, 1974, Fig. 31; Song et al., 1978, Fig. 9D), and P. praedatoria Schenkel (Song et al., 1978, Fig. 8E). This suggests that the insularis group is a widespread component of the world genus Pirata.

The purpose of this paper is to describe a new species of Pirata, the male of which also has a dorsal tooth on the median apophysis and which we therefore assign to the insularis group.

*Manuscript received by the editor January 23, 1981. 


\section{Pirata canadensis, n.sp.}

Figures 1-8

Types: Holotype: male, Whirlpool Lake, Riding Mountain National Park (R.M.N.P.), Manitoba (August 27, 1979; J. H. and M. Redner). Paratypes: 4 females, same data as holotype; 1 male, 2 females, same data except August 20, 21; 1 female, Whirlpool River, R.M.N.P., Manitoba (June 22, 1979; S. J. Miller); 7 males and 7 females, Swanson Spring, R.M.N.P., Manitoba (June 20-July 18, 1979; D. B. Lyons); 1 male, Wasagaming, R.M.N.P., Manitoba (August 29, 1979; J. H. and M. Redner); 1 male, Agassiz Forest Reserve, Manitoba (July 1, 1964); 2 males, 1 female, Poltimore, Papineau Co., Québec (May 18-August 3, 1979; J. H. Redner and C. D. Dondale); 3 males, 2 females, Kouchibouguac National Park, Kent Co., New Brunswick (June 8-August 16, 1977; G. A. Calderwood). The holotype and paratypes are deposited in the Canadian National Collection of Insects and Arachnids, Ottawa.

Etymology: The specific name is based on the name of the country in which the type-series was collected.

Diagnosis: Individuals of $P$. canadensis differ from those of the other North American species in the insularis group by being smaller (range of carapace length and width, respectively, 1.52-1.90 and 1.01-1.28 mm, contrasted with $2.00-3.45,1.32-2.55 \mathrm{~mm}$ for $P$. insularis and $2.17-2.71,1.50-2.06$ for $P$. cantralli). The carapace usually lacks the dark lateral rim found in individuals of the other species, and the venter of the abdomen often has three dark coalescent longitudinal bands, or a single broad dark area, rather than slender separate bands. The distitarsus of leg $I$ in males is also somewhat curved rather than straight.

Specimens of $P$. canadensis do not key to either insularis or cantralli in Wallace and Exline's (1978) key owing to the frequent lack of a dark lateral rim on the carapace and to the small body size.

Male: Total length approximately $3.00 \mathrm{~mm}$. Carapace $1.71 \pm 0.07$ $\mathrm{mm}$ long, $1.13 \pm 0.05 \mathrm{~mm}$ wide (15 specimens measured). Carapace shiny, somewhat irridescent; brown yellow or yellow orange, with margins sometimes somewhat darkened; usually with broad marginal pale area, paired dark longitudinal bands, and tuning-fork mark anterior to dorsal groove; posterior margin somewhat concave; lateral margins almost smoothly convex, strongly narrowed at level of coxae I and II; height approximately uniform from dorsal groove 

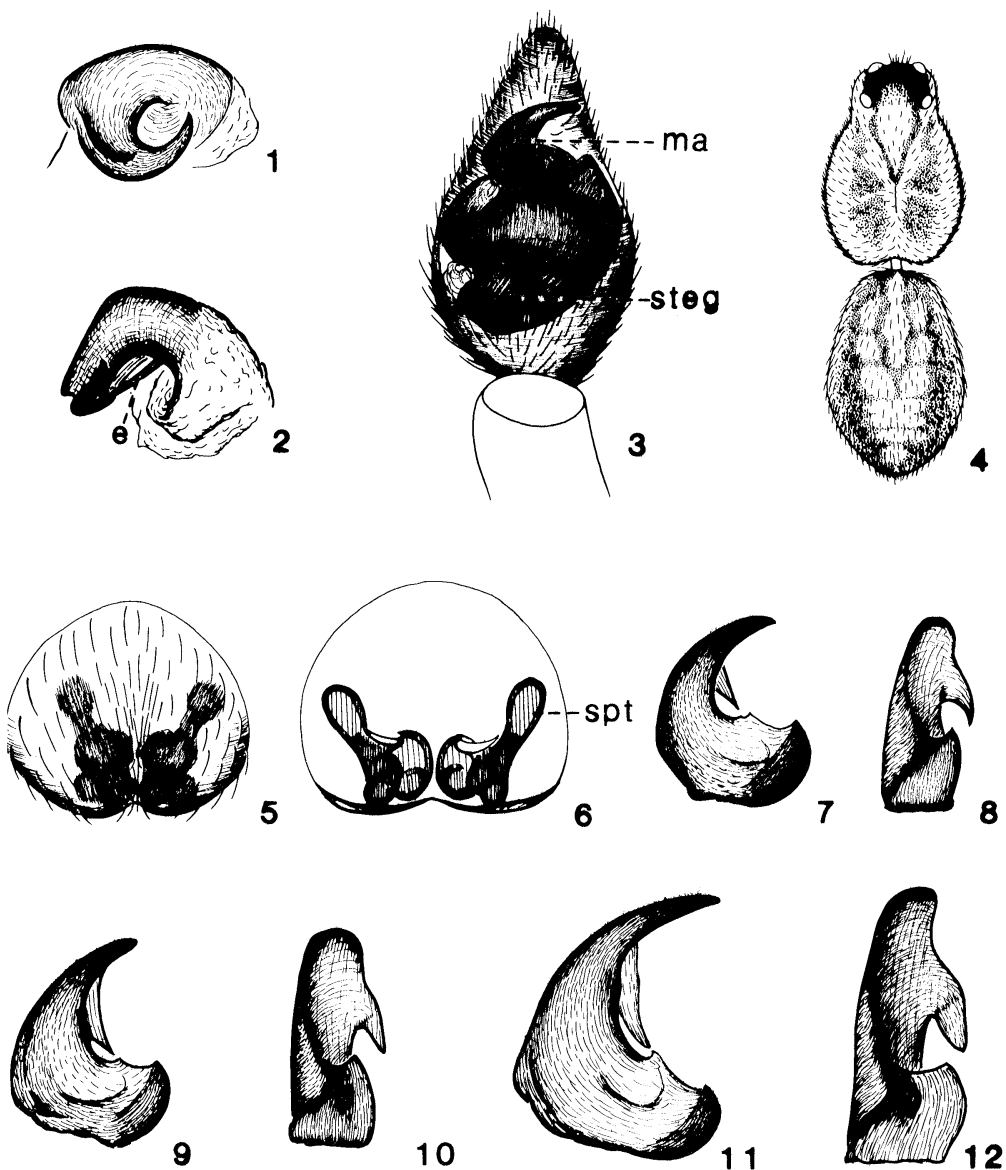

10
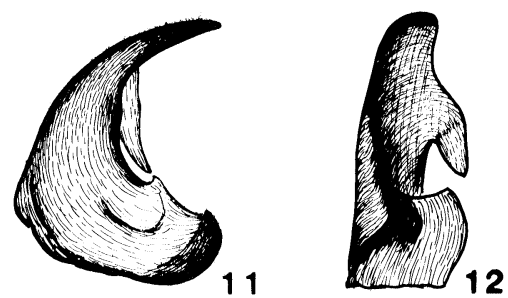

Figs. 1-12. Structures of Pirata spp. 1-8. P. canadensis n.sp. 1, 2. Apical division of left male genital bulb. 1. Ventral view. 2. Retrolateral view. 3. Male palpus, ventral view. 4. Body of female, dorsal view. 5. Epigynum, ventral view. 6. Epigynum, dorsal view, cleared. 7, 8. Median apophysis. 7. Ventral view. 8. Retrolateral view. 9, 10. Median apophysis of $P$. cantralli Wallace and Exline. 9. Ventral view. 10. Retrolateral view. 11, 12. Median apophysis of $P$. insularis Emerton. 11. Ventral view. 12. Retrolateral view. e, embolus. ma, median apophysis. spt, spermatheca. steg, subtegulum. 
to posterior row of eyes; front nearly vertical; setae short, dark, suberect, rather sparse. Anterior row of eyes shorter than middle row, somewhat procurved, approximately uniform in spacing, with anterior median eyes somewhat larger than anterior laterals. Sternum brown yellow, sometimes suffused with black or with indistinct pale median band and pale submarginal spots. Chelicerae brown yellow; promargin of fang furrow with 2 or 3 teeth and retromargin with 3 teeth. Legs pale brown yellow, with patella and tibia I somewhat darker, not annulated, somewhat irridescent; scopula sparse; femur I with 3 dorsal macrosetae, 1 prolateral, 0 retrolaterals; tibia I with 0 dorsal macrosetae (though 2 bristles present), 1 or 2 prolaterals, 0 retrolaterals, 3 pairs of ventrals; basitarsus I with 0 dorsal macrosetae, 1 to 3 prolaterals, 1 retrolateral, 2 pairs of ventrals plus 1 unpaired at tip; distitarsus I with slight curvature; trochanter with deep ventral notch at tip. Abdomen ovoid, brown yellow, with indistinct heart mark and dark reticulated pattern, occasionally lacking pattern, with cluster of erect curved setae at anterior end; venter pale brown yellow, often with a median and 2 lateral dark longitudinal bands coalescing or forming a median patch. Tibia of palpus nearly twice as long as wide. Subtegulum (steg) large, prominent, occupying approximately one-third length of genital bulb (Fig. 3); seminal duct sinuous, nearly transverse; median apophysis (ma) angular at base, long and curved at tip, with slender dorsal tooth (Figs. 3, 7, 8); embolus (e) short, slender, arising close to terminal apophysis on prolateral margin of genital bulb, held in groove formed by folded margin of terminal apophysis (Fig. 2); terminal apophysis with two minute processes (Figs. 1, 2).

Female: Total length approximately $3.75 \mathrm{~mm}$. Carapace $1.78 \pm$ $0.09 \mathrm{~mm}$ long, $1.19 \pm 0.06 \mathrm{~mm}$ wide (17 specimens measured). General structure and color (Fig. 4) essentially as in male but body sometimes lacking pattern; anterior median eyes sometimes equal to anterior laterals in size; patella and tibia I not darker than other segments; tibia I with distal pair of ventral macrosetae often missing; basitarsus I lacking ventral unpaired macroseta at tip, and distitarsus I not curved. Epigynum with plate somewhat longer than broad, rather convex, setaceous, lacking processes at posterior margin (Fig. 5). Copulatory tubes broad, each with rounded prominence posterolaterally; spermathecae (spt) longer than broad, extending anterolaterad, with minute nodules at tip (Fig. 6).

Material Examined: Only the type-series was examined. 
Range: Manitoba to New Brunswick.

Natural History: All of the available specimens were collected in pitfall traps or by sifters in sphagnum bogs. The paratypes from Poltimore, Québec were collected in a small bog with specimens of $P$. insularis and $P$. cantralli.

\section{REFERENCES CITED}

Fuhn, I. E. and F. Niculescu-Burlacu.

1971. Fauna Republicii Socialiste România, Arachnida, Volumul V, Fascicula 3, Fam. Lycosidae. Academia Republicii Socialiste România, Bucuresti.

HoLm, $\AA$. $256 \mathrm{pp}$.

1947. Svensk spindelfauna. 3. Egentliga spindlar. Araneae. Fam. 8-10, Oxyopidae, Lycosidae och Pisauridae. Entomologiska Föreningen, Stockholm. 48 pp.

Song, D. X., D. W. Shang, R. M. Wang, C. F. Cheng, and S. X. Cheng.

1978. On the wolf spiders from farm fields in Chekiang Province. Zool. Mag. 2:1-5 (Chinese).

TANAKa, $\mathrm{H}$.

1974. Japanese wolf spiders of the genus Pirata, with descriptions of five new species (Araneae:Lycosidae). Acta Arachnol. 26: 22-45.

Wallace, H. K. and H. Exline

1978. Spiders of the genus Pirata in North America, Central America and the West Indies (Araneae:Lycosidae). J. Arachnol. 5:1-112. 

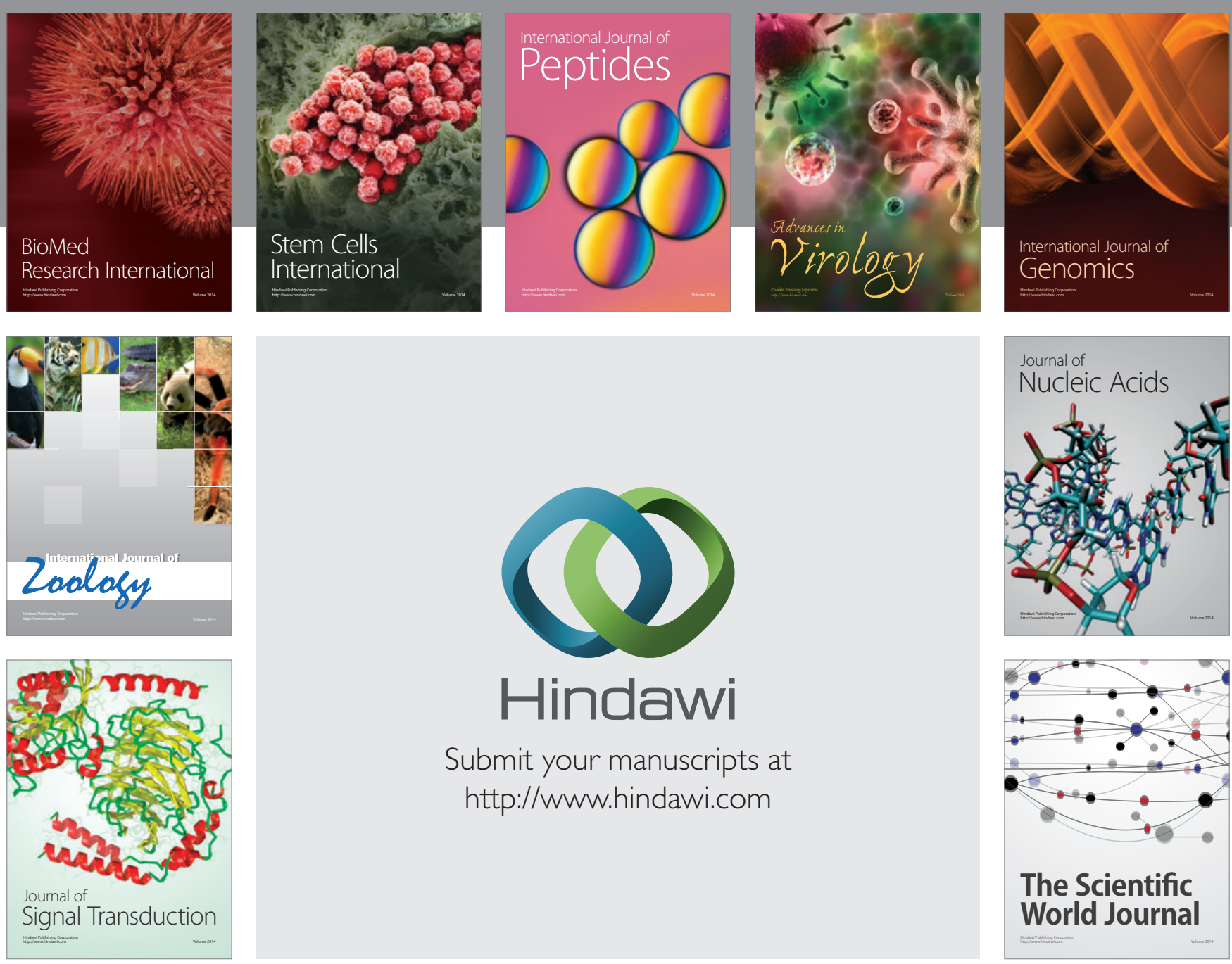

Submit your manuscripts at

http://www.hindawi.com
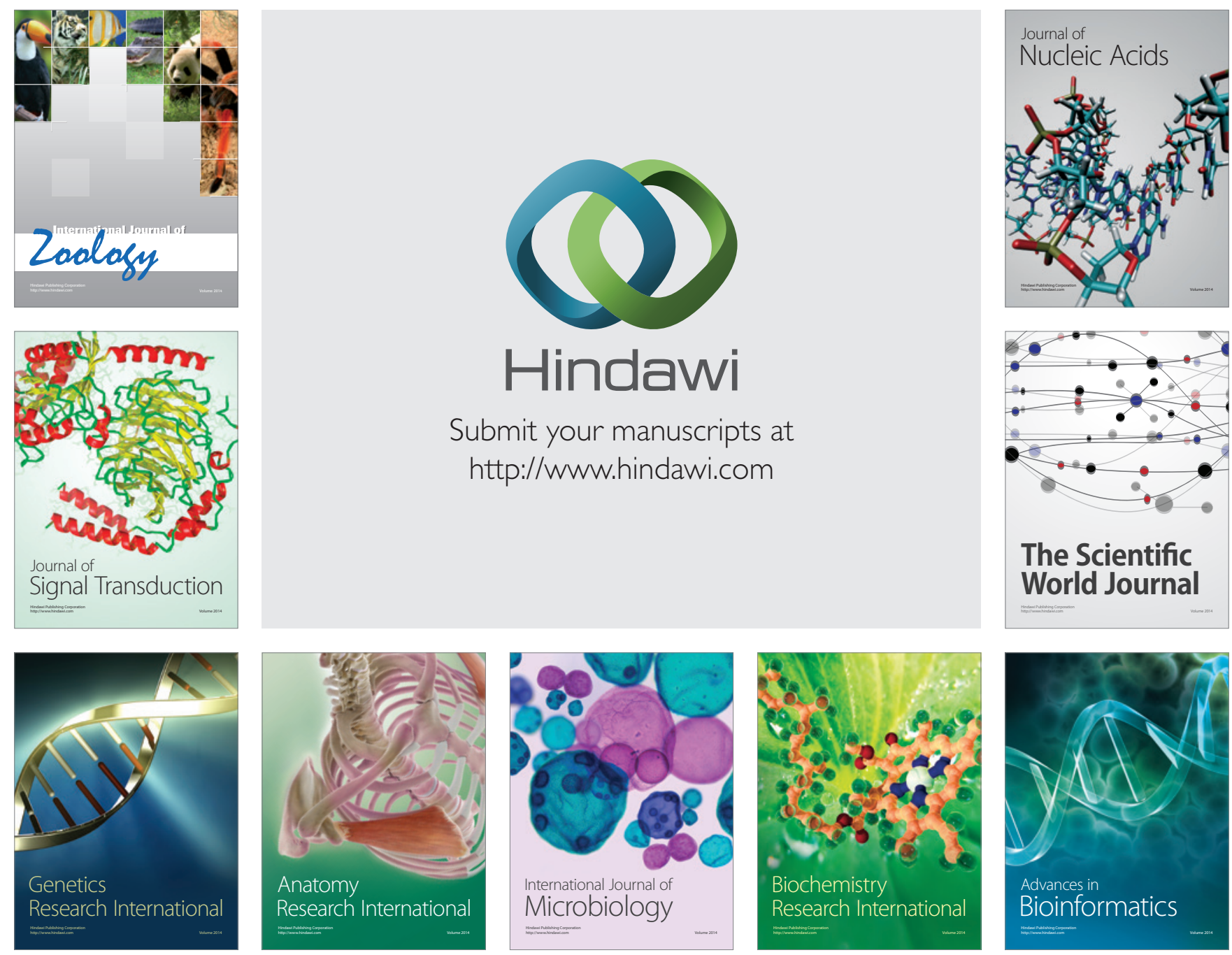

The Scientific World Journal
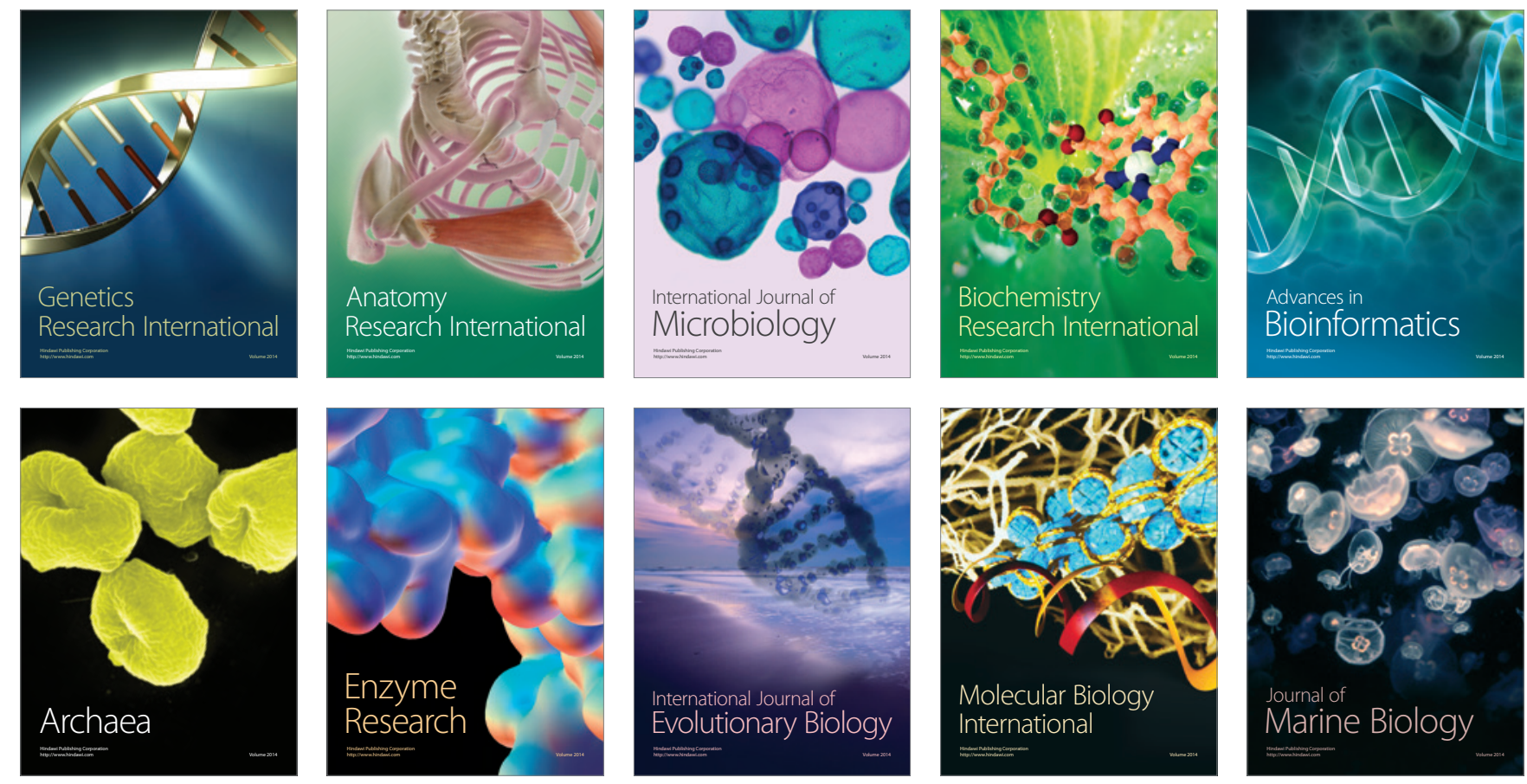